\title{
Physical condition of pupils of pre-school educational establishments of different types
}

\author{
Moskalenko N.V. ${ }^{\mathrm{ABCDE}}$, Savchenko V.G. ${ }^{\mathrm{ABCDE}}$, Polyakova A.V. ${ }^{\mathrm{ABCDE}}$, Mikitchik O.S. ${ }^{\mathrm{ABCDE}}$, Mitova O.O. ${ }^{\mathrm{ABCDE}}$, \\ Griukova V.V. ${ }^{\mathrm{ABCDE}}$, Mytsak A.V. ${ }^{\mathrm{ABCDE}}$ \\ Dnieper State Academy of Physical Culture and Sports, Ukraine
}

Authors' Contribution: A - Study design; B - Data collection; C - Statistical analysis; D - Manuscript Preparation; E - Funds Collection.

\begin{abstract}
Purpose:

The purpose of the study is to determine the physical condition of the pupils of pre-school educational establishments of various types for improving the quality of the educational process of physical education.

Material: $\quad$ The study involved 3-4 year-old children. The children attended preschool institutions of various types in the city of Dnipro. They were the children's educational establishment №282 of the combined type, the children's educational establishment №192 of the sanatorium type, the children's educational establishment №28 of the compensating type, children's educational establishment №244 and №404 of general development. Control $(n=90)$ and experimental $(n=95)$ groups were created in each age group of a particular type of institution. The differentiation of pupils of institutions of different types into two subgroups was caused by their differences in functional indicators and health status. At the beginning of the experiment, the homogeneity of the studied groups of children was noted $(p>0.05)$.

Results: $\quad$ The model of organization of rational motor mode of 3-4 year-old children has been substantiated and developed. Organizational and methodological bases of realization of the model of rational motor mode of 3-4 year-old children in preschool educational institutions of various types have been developed. The influence of the developed model on the physical condition of pupils of pre-school educational institutions of different types has been determined. The study of the anthropometric parameters of children after the implementation of the developed model showed no differences in these parameters. These differences were observed in children of different types of kindergartens in all sex-age groups. The determination of functional abilities of children resulted in a significant improvement in spirometry, respiratory rate, heart rate, Ruffier test in experimental groups of children of both sexes $(p<0.05)$. The indicators of the functional state of the cardiovascular system and physical performance of the pupils of preschool educational establishments of the sanatorium type and the compensating type were lower than the similar indicators of the pupils of general development establishments. The indicators of heart rate of real rest and respiratory rate of children of experimental groups of institutions of the sanatorium and compensating type corresponded to the average level.

Conclusions: $\quad$ The obtained result of this empirical study confirms the hypothesis that the organization of rational movement mode for 3-4 year-old children contributes to improving of their physical condition. The obtained results indicate the improvement of the quality of the educational process of physical education of children in pre-school educational establishments of different types.

Keywords: physical condition, schoolchildren, motor, physical education.
\end{abstract}

\section{Introduction}

Nowadays, the development of the world society is accompanied by complex social and economic problems. These problems have led to the deterioration of the physical, mental and financial status of most of the population. In particular the concern is about the health declining of preschool children $[1,2]$. This leads to the development of new approaches to achieve the primary goal of physical education which is health promotion. In particular, Canada, South Africa, Kenya and Louisiana have summarized data from studies of children's involvement in various forms of locomotor activity. [3]. Marouli with co-authors determined the impact of the psychomotor program on motor knowledge and selfperception of pre-school children in Greece [4]. Savich considered the issue of motor movement of children from the medical point of view [5]. Moskalenko and (c) Moskalenko N.V., Savchenko V.G, Polyakova A.V., Mikitchik O.S., Mitova O.O., Griukova V.V., Mytsak A.V., 2020 doi:10.15561/26649837.2020.0205 her co-authors have proposed modern approaches to the organization of physical and recreation work in preschool institutions of Ukraine [6]. Suporosova implemented the methods of organization of motor mode for children with visual impairment in Russia [7].

Scientists emphasize the presence of interconnection between motor activity and physical development of the child. This determines the feasibility of using a training system with maximum health, educational and educational effects $[1,2,7]$. Attention is drawn to the uneven and irregular process of physical development of children. This is connected with the first rounding period of children aged 1 to 4 years old. This age is characterized by an annual increase in weight with a relatively small body height. Exactly at this age the mechanisms of personal growth also begin to develop [8].

In recent years, studies have been conducted on improving the efficiency of physical education in preschool institutions. The organizational pedagogical 
and methodological basis for improving the system of physical education of preschool children is given in the researches of Vil'chkovs'kij et al. [1]. Theoretical and methodological foundations of the formation of a harmoniously developed personality of a preschool child in the process of physical education are given in the studies by Panhelova [8]. The analysis of the indicators of physical and motor readiness of children of preschool age was carried out in the works of Gonchar et al. [9]. Stork et al. considered some issues of physical education in early childhood [10]. The peculiarities of the use of oriental health systems in the physical education of older preschool children are reflected in the studies by Panhelova et al. [11, 12]. Innovative technologies of development of psychomotor abilities in physical education of children from the 2nd to the 5th years of life are revealed in the work of Lakhno [13]. Bondar [14] investigated the condition of the musculoskeletal system of children aged 3-4 years old.

The analysis of the literature shows that scientists are interested in finding unexplained problems of the physical education of preschool children and the ways to solve them. However, the issues of optimization of the motor mode of 3-4 year old pupils of preschool educational institutions of different types are still unclear. This has made the topic under research relevant.

Hypothesis. It was envisaged that the organization of rational movement mode of 3-4 year old children will contribute to the improvement of their physical condition and quality of the educational process of physical education.

The purpose of the study is to determine the physical condition of the pupils of pre-school institutions of various types for improving the quality of the educational process of physical education.

\section{Material and methods.}

Participants. The study involved children aged 3-4 years old. They visited preschool educational establishments of various types in the city of Dnipro. They were the children's educational establishment №282 of the combined type, the children's educational establishment №192 of the sanatorium type, the children's educational establishment №28 of the compensating type, children’s educational establishment №244 and №404 of general development. Control and experimental groups were established in each age group of the kindergarten of a certain type. The control groups consisted of 90 children, the experimental groups of 95 . The differentiation of pupils of institutions of different types into two subgroups was due to their differences in functional indicators and health status.

At the beginning of the experiment, the homogeneity of the studied groups of children was noted ( $p>0.05)$. The parents of the participants of the research gave the written consent to their children's participation in the study. All permits for the scientific research in the preschool institutions were obtained.

Organization of the research. Anthropometric and index methods were used to assess the physical development and harmony of the physique of preschoolers. At the beginning of the experiment, the homogeneity of the studied groups of children of all types of preschool institutions was noted in terms of height, body weight and chest girth ( $>0.05)$. The average values of anthropometric indicators according to the standards table corresponded to the average level of development. The condition of the musculoskeletal system of children was evaluated by a preschool establishment doctor.

To assess the functional state of the cardiovascular and respiratory systems physiological methods (heart rate, spirometry) were used $[15,16]$. To determine the physical performance of the organism of preschoolers the Ruffier test was used [17]. The Ruffier test was conducted as follows. The first measurement of the child's pulse after a five-minute rest was made. Then the child does 30 squats in 45 seconds. The pulse was recorded in 15 seconds. After one minute of rest, the last pulse measurement is performed. On the basis of the values obtained, the doctor calculated an individual indicator of the child's heart capacity.

Physical education classes with children of experimental groups were conducted according to the developed model of organization of rational motor mode of children aged 3-4 years old with different level of physical condition. The content of this model includes the content of their motor activity. It has been experimentally tested in the process of conducting of various organizational forms of physical education in the conditions of work of preschool educational institutions of different types. These are physical education, physical and health activities in the day mode, active rest, and independent activity of children.

In experimental groups of preschool educational institutions of different types, the motor mode was constructed on the basis of the developed parameters of motor activity, content and organizational and methodological principles of motor activity of younger preschool children. They corresponded to the profile of these preschool institutions. It was suggested to include elements of recreation and innovative pedagogical technologies of physical education. These elements contribute to the optimization of the motor mode in the conditions of preschool education, in combination with the program material of education and upbringing of children to all organizational forms of work in physical education. The specificity of a preschool educational institution of a certain type was also taken into account.

The content of the motor activity of the pupils of institutions of general development and of the combined type was supplemented by the author's methods, means of psychoprophylactic work, children's fitness, hardening measures. We have proposed integrating innovative and recreational technologies into all organizational forms of physical educational work. The game class of physical culture was held at least twice a week. Such classes contained elements of fairytale therapy, eurhythmic gymnastics, and children's fitness. The techniques of 
“Children's experimentation", "Little wizards", "Learning in motion" and technologies of complex development of the child's personality were involved.

In the preschool institution №404 a physical training in swimming was held in the afternoon twice a week. The main physical and health activities were morning gymnastics, motion games on a walk, gymnastics after afternoon's sleep. They included elements of psychogymnastics, correction gymnastics, recreational running. Hardening events were held at least three times a week. Corrective gymnastics included elements of logarithmic gymnastics, exercises for the development of fine motor skills. Active rest for children of the middle group included holding of physical culture festivals once every 3 months. Health days were held once a month. Twice a month sports fun activities took place. For the children of the middle group 2-3 times a month hiking walks in the woods or the nearest park were offered. Independent motor activity of children was organized daily under the guidance of the tutor, taking into account the level of motor activity of the children.

The pupils of preschool educational institutions of the sanatorium and compensating type had physical training sessions three times a week. Their content has been supplemented by author's techniques. These are "Theater of physical education", "Free physical education", technology of integral development of psychomotor abilities of the children aged 2-5 years old. Elements of psycho-prophylactic work, elements of Sa-Phi-Dance children's fitness program [18] and corrective gymnastics were involved. Corrective gymnastics contained training complexes using SIT-45 healing balls. The organization of physical and health events, along with the traditional ones, provided daily conducting of health and play classes. The content of forms of active rest and self-motor activity provided the use of traditional and proposed innovative means of preschool physical education. During the organization of all forms of physical education work in preschool educational institutions of different types, we took into account the proposed parameters of physical activity.

In all groups, physical education classes were conducted by a physical education instructor. Physical and health activities in the day mode were conducted by the tutor. The active rest of the children in the experimental groups was organized and conducted by the tutor of the groups and the instructor of the physical culture of the institution. The correction of independent physical activity of children was managed by the tutor.

The classes were conducted with the observance of all methodical recommendations concerning movement training and development of physical abilities.

In control groups physical training and recreation were conducted according to the plan of the institution, taking into account the regulatory requirements.

Statistical analysis. Statistical processing of the study materials was conducted using Microsoft Excel 2010. The arithmetic mean and the bias of the arithmetic mean were calculated. The credibility of differences between sample rates was tested using the Student's t-test and considered statistically significant at $\mathrm{p}<0.05$.

\section{Results}

Assessment of the musculoskeletal system of children revealed an increase in the number of postural disorders in all categories of children. It was found out that $50 \%$ of boys and girls of the age 3 years old among the pupils of the combined type preschool educational establishments have postural disorders. The number of violations was $67-69 \%$ among the children of the sanatorium and compensatory type. It was recorded that 4-year old children have $65 \%$ and $71 \%$ of cases of musculoskeletal disorders, respectively. The kyphotic type of postural disorders is most often found in $40 \%$ of preschool children of sanatorium and compensatory types. $21.2-24.1 \%$ of children with poor health and $19.1-23.5 \%$ of pupils of pre-school educational institutions of combined type were found to have a disorder of the posture of scoliotic type.

Adaptation capacity of the organism of the pupils of the institutions of sanatorium and compensatory types was lower than that of the pupils of the preschool institutions of general development.

The results of the comparative analysis of testing data of children aged 3-4 years old from control and experimental groups confirmed the effectiveness of the proposed measures (Table 1-4). At the beginning of the study, no statistically significant difference between the groups was observed.

The dynamics of indicators of physical development was one of the criteria for the effectiveness of the proposed model of the organization of rational motor mode of children aged 3-4 years old in preschool institutions of various types.

Comparisons of the average values of anthropometric parameters showed the absence of differences of children of control and experimental sex-age groups of different types of preschool institutions

According to the Kettle weight-height index, the children of the studied groups mostly had already had the average level of physical development.

The study of the functional abilities of the studied groups of children resulted in a significant improvement in the spirometry, respiratory rate, heart rate, Ruffier test in the experimental groups of children aged 3 and 4 years old of both sexes $(\mathrm{p}<0.05)$.

The pupils of sanatorium and compensating types of institutions proved to have lower indicators of the functional state of the cardiovascular system and physical performance than the pupils' of general development establishments similar indicators. The indicators of heart rate at real rest and respiratory rate of children from experimental groups of institutions of the sanatorium and compensating type corresponded to the average level.

\section{Discussion}

The analysis of literary sources on the problem of research and generalization of practical experience allowed to establish the basis of the system of physical 
Table 1. The indices of functional condition of 3 year-old girls $(n=60)$

\begin{tabular}{|c|c|c|c|c|c|}
\hline \multirow{3}{*}{ Indices } & \multirow{3}{*}{ Type of the establishment } & \multicolumn{2}{|c|}{$\begin{array}{l}\text { At the beginning of the } \\
\text { research }\end{array}$} & \multicolumn{2}{|c|}{ At the end of the research } \\
\hline & & CG & EG & CG & EG \\
\hline & & $\bar{x} \pm \mathrm{m}$ & & $\bar{x} \pm \mathrm{m}$ & \\
\hline \multirow{3}{*}{ Length of the body, sm } & general development** & & & & \\
\hline & and combined type & $100.0 \pm 0.75$ & $99.8 \pm 0.86$ & 9 & \\
\hline & $\begin{array}{l}\text { sanatorium and } \\
\text { compensating type } * * *\end{array}$ & $97.0 \pm 0.94$ & $96.8 \pm 0.78$ & $99.5 \pm 0.59$ & $99.7 \pm 0.61^{*}$ \\
\hline \multirow{2}{*}{ Weight of the body, kg } & $\begin{array}{l}\text { general development } \\
\text { and combined type }\end{array}$ & $14.7 \pm 0.32$ & $14.3 \pm 0.22$ & $16.2 \pm 0.38$ & $15.9 \pm 0.41^{*}$ \\
\hline & $\begin{array}{l}\text { sanatorium and } \\
\text { compensating type }\end{array}$ & $97.0 \pm 0.94$ & $96.7 \pm 0.78$ & $99.5 \pm 0.59$ & $99.7 \pm 0.61^{*}$ \\
\hline \multirow{2}{*}{$\begin{array}{l}\text { Weight-height index, } r \bullet \\
\mathrm{sm}^{-1}\end{array}$} & $\begin{array}{l}\text { general development } \\
\text { and combined type }\end{array}$ & $146.7 \pm 2.98$ & $145.2 \pm 2.45$ & $164.2 \pm 2.67$ & $167.3 \pm 2.53 *$ \\
\hline & $\begin{array}{l}\text { sanatorium and } \\
\text { compensating type }\end{array}$ & $147.6 \pm 2.55$ & $146.6 \pm 2.34$ & $163.4 \pm 2.38$ & $165.7 \pm 2.71 *$ \\
\hline \multirow{2}{*}{$\begin{array}{l}\text { Heart rate at real rest } \\
\text { beats } \min ^{-1}\end{array}$} & $\begin{array}{l}\text { general development } \\
\text { and combined type }\end{array}$ & $104 \pm 0.41$ & $104 \pm 0.23$ & $103 \pm 0.61$ & $99 \pm 0.51 *$ \\
\hline & $\begin{array}{l}\text { sanatorium and } \\
\text { compensating type }\end{array}$ & $109 \pm 0.45$ & $109 \pm 0.34$ & $108 \pm 0.51$ & $104 \pm 0.61 *$ \\
\hline \multirow{2}{*}{$\begin{array}{l}\text { Vital capacity of the lungs, } \\
\text { ml }\end{array}$} & $\begin{array}{l}\text { general development } \\
\text { and combined type }\end{array}$ & $910 \pm 11.4$ & $905 \pm 11.2$ & $950 \pm 11.3$ & $1100 \pm 10.9 *$ \\
\hline & $\begin{array}{l}\text { sanatorium and } \\
\text { compensating type }\end{array}$ & $875 \pm 10.5$ & $835 \pm 11.0$ & $920 \pm 10.7$ & $980 \pm 11.2 *$ \\
\hline \multirow{2}{*}{$\begin{array}{l}\text { Frequency of respiratory } \\
\text { cycles, } \min ^{-1}\end{array}$} & $\begin{array}{l}\text { general development } \\
\text { and combined type }\end{array}$ & $27 \pm 0.53$ & $26 \pm 0.57$ & $27 \pm 0.51$ & $23 \pm 0.27^{*}$ \\
\hline & $\begin{array}{l}\text { sanatorium and } \\
\text { compensating type }\end{array}$ & $31.5 \pm 0.61$ & $31.1 \pm 0.49$ & $30 \pm 0.32$ & $25 \pm 0.21 *$ \\
\hline \multirow{2}{*}{ Ruffier Index, points } & $\begin{array}{l}\text { general development } \\
\text { and combined type }\end{array}$ & $10.8 \pm 0.67$ & $10.2 \pm 0.43$ & $9.2 \pm 0.41$ & $6.9 \pm 0.31 *$ \\
\hline & $\begin{array}{l}\text { sanatorium and } \\
\text { compensating type }\end{array}$ & $12.9 \pm 0.74$ & $13.1 \pm 0.13$ & $11.8 \pm 0.31$ & $9.7 \pm 0.23 *$ \\
\hline
\end{tabular}

Notes: * - $p<0.05$ compared to the values recorded in the control and experimental groups at the beginning and end of the experiment; ${ }^{* *}$ - number of children in the institution of general development and combined type in the control group $(n=15)$, in the experimental group $(n=15) ; * * *$ number of children in the sanatorium and compensatory type institution in the control group $(n=15)$, in the experimental group $(n=15)$; EG - experimental group; KG control group.

education in pre-school educational institutions. This is motor mode. It is a collection of different tools and organizational forms of working with children. These forms should be rationally combined and consistently used according to the age of the children and their physical condition. The leading factor in increasing of the level of physical condition of children is motor activity within the optimal values. At present, there is insufficient certainty in the scientific and methodological literature regarding the content, organizational and methodological features and parameters of the motor activity of children in the mode of day of preschool educational institutions of various types.

The research conducted was based on the data of Stork et al. [10] on particular issues of physical education in early childhood.

The model of organization of rational motor mode of 3-4year-old children in preschool educational establishments of different types is substantiated and developed. This model has the purpose, objectives, content, pedagogical conditions of optimization of physical activity in the mode of day of the kindergarten. We have developed the organizational and methodological foundations for the implementation of the model of rational motor mode of children aged 3-4 years old. The advantage of our research is in the implementation of the motor mode of children, taking into account the specific pre-school educational institution of a certain type. We have proposed the inclusion of elements of recreation and innovative pedagogical technologies of physical 
Table 2.The indices of functional condition of 3 year-old boys $(n=49)$

\begin{tabular}{|c|c|c|c|c|c|}
\hline \multirow{3}{*}{ Indices } & \multirow{3}{*}{ Type of the establishment } & \multicolumn{2}{|c|}{$\begin{array}{l}\text { At the beginning of the } \\
\text { research }\end{array}$} & \multicolumn{2}{|c|}{ At the end of the research } \\
\hline & & CG & EG & CG & EG \\
\hline & & $\bar{x} \pm \mathrm{m}$ & & $\bar{x} \pm \mathrm{m}$ & \\
\hline \multirow{3}{*}{$\begin{array}{l}\text { Length of the } \\
\text { body, sm }\end{array}$} & general development & & & & \\
\hline & and combined type** & $101.6 \pm 0.83$ & $1014 \pm 0.76$ & $102.9 \pm 0.79$ & $103.1 \pm 0.82^{*}$ \\
\hline & $\begin{array}{l}\text { sanatorium and } \\
\text { compensating type }\end{array}$ & $100.0 \pm 0.94$ & $99.6 \pm 0.91$ & $102.1 \pm 0.91$ & $102.4 \pm 0.83^{*}$ \\
\hline \multirow{3}{*}{$\begin{array}{l}\text { Weight of the } \\
\text { body, kg }\end{array}$} & general development & $14.7 \pm 0.34$ & $14.3 \pm 0.41$ & $16.1+0.37$ & $16.3 \pm 0.44 *$ \\
\hline & and combined type & & & & \\
\hline & $\begin{array}{l}\text { sanatorium and } \\
\text { compensating type }\end{array}$ & $14.9 \pm 0.60$ & $14.2 \pm 0.56$ & $16.4 \pm 0.71$ & $16.7 \pm 0.63^{*}$ \\
\hline \multirow{2}{*}{$\begin{array}{l}\text { Weight-height } \\
\text { index, } r \cdot \mathrm{sm}^{-1}\end{array}$} & $\begin{array}{l}\text { general development } \\
\text { and combined type }\end{array}$ & $144.3 \pm 2.91$ & $143.8 \pm 2.67$ & $162.7 \pm 3.71$ & $164.7 \pm 2.47^{*}$ \\
\hline & $\begin{array}{l}\text { sanatorium and } \\
\text { compensating type }\end{array}$ & $149.3 \pm 6.35$ & $149.6 \pm 6.21$ & $167.1 \pm 4.21$ & $169.2 \pm 3.71^{*}$ \\
\hline \multirow{2}{*}{$\begin{array}{l}\text { Heart rate at } \\
\text { real rest beats } \\
\text { min }^{-1}\end{array}$} & $\begin{array}{l}\text { general development } \\
\text { and combined type }\end{array}$ & $102 \pm 0.44$ & $102 \pm 0.23$ & $101 \pm 0.32$ & $97 \pm 0.31^{*}$ \\
\hline & $\begin{array}{l}\text { sanatorium and } \\
\text { compensating type }\end{array}$ & $108 \pm 0.43$ & $108 \pm 0.27$ & $106 \pm 0.41$ & $102 \pm 0.23^{*}$ \\
\hline \multirow{2}{*}{$\begin{array}{l}\text { Vital capacity } \\
\text { of the lungs, } \\
\mathrm{ml}\end{array}$} & $\begin{array}{l}\text { general development } \\
\text { and combined type }\end{array}$ & $933 \pm 9.53$ & $932 \pm 9.34$ & $950 \pm 6.41$ & $1100 \pm 4.4^{*}$ \\
\hline & $\begin{array}{l}\text { sanatorium and } \\
\text { compensating type }\end{array}$ & $850 \pm 5.13$ & $851 \pm 5.24$ & $870 \pm 4.17$ & $990 \pm 7.21^{*}$ \\
\hline \multirow{2}{*}{$\begin{array}{l}\text { Frequency of } \\
\text { respiratory } \\
\text { cycles, } \text { min }^{-1}\end{array}$} & $\begin{array}{l}\text { general development } \\
\text { and combined type }\end{array}$ & $27 \pm 0.63$ & $27 \pm 0.49$ & $27 \pm 0.43$ & $22 \pm 0.21 *$ \\
\hline & $\begin{array}{l}\text { sanatorium and } \\
\text { compensating type }\end{array}$ & $32 \pm 0.71$ & $32 \pm 0.65$ & $31 \pm 0.37$ & $24 \pm 0.31 *$ \\
\hline \multirow{2}{*}{$\begin{array}{l}\text { Ruffier Index, } \\
\text { points }\end{array}$} & $\begin{array}{l}\text { general development } \\
\text { and combined type }\end{array}$ & $10.6 \pm 0.71$ & $10.2 \pm 0.89$ & $10.0 \pm 0.53$ & $7.0 \pm 0.37^{*}$ \\
\hline & $\begin{array}{l}\text { sanatorium and } \\
\text { compensating type }\end{array}$ & $13.6 \pm 0.96$ & $13.1 \pm 0.53$ & $12.1 \pm 0.58$ & $9.7 \pm 0.31 *$ \\
\hline
\end{tabular}

Notes: ${ }^{*}-p<0.05$ compared to the values recorded in the control and experimental groups at the beginning and end of the experiment; ${ }^{*}$ - number of children in the institution of general development and combined type in the control group $(n=12)$, in the experimental group $(n=14) ; * *$ - number of children in the sanatorium and compensatory type institution in the control group $(n=11)$, in the experimental group $(n=12)$; EG - experimental group; KG control group.

education.

It was proposed to supplement the content of motor activity of pupils of general development and combined types by author's methods, means of psycho-prophylactic work, children's fitness, and hardening measures. The recommended elements of innovative and recreation technologies are the elements of fairytale therapy, eurhythmic gymnastics, and children's fitness. It is advisable to conduct physical training in swimming. It was advised to include the elements of psycho-gymnastics, correction gymnastics, recreational running into morning gymnastics, moving games walks, gymnastics after afternoon's sleep. It is worth carrying out hardening at least three times a week. The content of correction gymnastics should include elements of logarithmic gymnastics, exercises for the development of fine motor skills.

It was suggested to conduct physical training by the author's methods for the students of sanatorium and compensating institutions. It is recommended to include the elements of psycho-prophylactic work, elements of Sa-Phi-Dance children's fitness program and corrective gymnastics.

Polyakova [19] motor activity parameters were taken into account while organizing all forms of physical education work in pre-school educational institutions of different types.

The results of our research were supplemented by the data of Suporosova [7] concerning the organization of locomotor mode in preschool institutions. We supplemented the data of Holubeva [20] on the absence of a significant difference between the parameters of motor 
Table 3. The indices of functional condition of 4 year-old girls $(n=41)$

\begin{tabular}{|c|c|c|c|c|c|}
\hline \multirow{3}{*}{ Indices } & \multirow{3}{*}{$\begin{array}{l}\text { Type of the } \\
\text { establishment }\end{array}$} & \multicolumn{2}{|c|}{$\begin{array}{l}\text { At the beginning of the } \\
\text { research }\end{array}$} & \multicolumn{2}{|c|}{ At the end of the research } \\
\hline & & CG & EG & CG & EG \\
\hline & & $\bar{x} \pm \mathbf{m}$ & & $\bar{x} \pm \mathbf{m}$ & \\
\hline \multirow{3}{*}{ Length of the body, sm } & general development & $1070+156$ & $1060+1$ & $100+151$ & $1102+151 *$ \\
\hline & and combined type** & 107.01 .50 & $100.011 .4 \mathrm{~J}$ & $107.011 . J 1$ & 110.211. \\
\hline & $\begin{array}{l}\text { sanatorium and } \\
\text { compensating type }\end{array}$ & $108.5 \pm 1.47$ & $108.1 \pm 1.32$ & $110.1 \pm 1.31$ & $111.0 \pm 1.61^{*}$ \\
\hline \multirow{2}{*}{ Weight of the body, kg } & $\begin{array}{l}\text { general development } \\
\text { and combined type }\end{array}$ & $17.8 \pm 0.65$ & $17.7 \pm 0.76$ & $19.2 \pm 0.68$ & $19.5 \pm 0.71^{*}$ \\
\hline & $\begin{array}{l}\text { sanatorium and } \\
\text { compensating type }\end{array}$ & $18.8 \pm 0.71$ & $18.1 \pm 0.56$ & $20.2 \pm 0.81$ & $20.3 \pm 0.61^{*}$ \\
\hline \multirow[b]{2}{*}{$\begin{array}{l}\text { Weight-height index, } r \bullet \\
\mathrm{sm}^{-1}\end{array}$} & & $166.8 \pm 4.22$ & $166.1 \pm 4.01$ & $178.7 \pm 5.71$ & $181.2 \pm 6.12 *$ \\
\hline & $\begin{array}{l}\text { and combined type } \\
\text { sanatorium and } \\
\text { compensating type }\end{array}$ & $172.5 \pm 5.43$ & $171.3 \pm 4.65$ & $183.2 \pm 4.71$ & $185.4 \pm 5.67^{*}$ \\
\hline \multirow{2}{*}{$\begin{array}{l}\text { Heart rate at real rest beats } \\
\min ^{-1}\end{array}$} & $\begin{array}{l}\text { general development } \\
\text { and combined type }\end{array}$ & $95 \pm 0.51$ & $95 \pm 0.43$ & $94 \pm 0.73$ & $91 \pm 0.51 *$ \\
\hline & $\begin{array}{l}\text { sanatorium and } \\
\text { compensating type }\end{array}$ & $102 \pm 0.81$ & $102 \pm 0.72$ & $102 \pm 0.67$ & $96 \pm 0.74 *$ \\
\hline \multirow{2}{*}{$\begin{array}{l}\text { Vital capacity of the lungs, } \\
\mathrm{ml}\end{array}$} & $\begin{array}{l}\text { general development } \\
\text { and combined type }\end{array}$ & $1020 \pm 916.6$ & $1020 \pm 911.3$ & $1050 \pm 7.91$ & $1290 \pm 5.83^{*}$ \\
\hline & $\begin{array}{l}\text { sanatorium and } \\
\text { compensating type }\end{array}$ & $890 \pm 17.6$ & $890 \pm 16.8$ & $920 \pm 9.71$ & $1090 \pm 8.93 *$ \\
\hline \multirow[t]{2}{*}{$\begin{array}{l}\text { Frequency of respiratory } \\
\text { cycles, } \mathrm{min}^{-1}\end{array}$} & $\begin{array}{l}\text { general development } \\
\text { and combined type }\end{array}$ & $25 \pm 0.61$ & $25 \pm 0.49$ & $25 \pm 0.31$ & $21 \pm 0.11 *$ \\
\hline & $\begin{array}{l}\text { sanatorium and } \\
\text { compensating type }\end{array}$ & $29.5 \pm 0.55$ & $29.15 \pm 0.24$ & $28 \pm 0.21$ & $24 \pm 0.12 *$ \\
\hline \multirow{2}{*}{ Ruffier Index, points } & $\begin{array}{l}\text { general development } \\
\text { and combined type }\end{array}$ & $8.5 \pm 0.75$ & $8.1 \pm 0.25$ & $8.2 \pm 0.53$ & $6.9 \pm 0.23 *$ \\
\hline & $\begin{array}{l}\text { sanatorium and } \\
\text { compensating type }\end{array}$ & $12.3 \pm 0.80$ & $12.6 \pm 0.12$ & $12.0 \pm 0.61$ & $9.3 \pm 0.47^{*}$ \\
\hline
\end{tabular}

Notes: ${ }^{*}-p<0.05$ compared to the values recorded in the control and experimental groups at the beginning and end of the experiment; ${ }^{* *}$ - number of children in the institution of general development and combined type in the control group $(n=10)$, in the experimental group $(n=11) ;{ }^{* * *}$ - number of children in the sanatorium and compensatory type institution in the control group $(n=10)$, in the experimental group $(n=10)$; $E G$ - experimental group; KG control group.

activity of boys and girls of the related age groups (3-4 years old) in one health group.

The opinion of Panhelova [8] on the fact that to solve the problem it necessary to optimize the motor mode of children with deviations of health state, to enhance specific forms and means of rehabilitation, rather than to increase the frequency of physical education per a week was confirmed.

The ideas of Marouli et al. [4] on the impact on motor skills and self-perceptions of preschool children were expanded.

The data of Lakhno [13], Panhelova [8] about specificity of development concerning the ontogeny of physical abilities of 3-4 year-old children and also the data of Bondar [14] on the condition of the musculoskeletal system of 3-4 year-old children were confirmed.

Harrington and co-authors [3] research on the involvement of preschool children in various forms of locomotor activity was further developed.

\section{Conclusions}

The result of this empirical study confirms the hypothesis that the organization of rational movement mode of children aged 3-4 years old contributes to improving their physical condition. The results obtained indicate the improvement of the quality of the educational process of physical education of children in kindergartens of different types.

\section{Acknowledgments}

The research was carried out in accordance with the 
Table 4. The indices of functional condition of 4 year-old boys $(n=49)$

\begin{tabular}{|c|c|c|c|c|c|}
\hline \multirow{3}{*}{ Indices } & \multirow{3}{*}{ Type of the establishment } & \multicolumn{2}{|c|}{$\begin{array}{l}\text { At the beginning of the } \\
\text { research }\end{array}$} & \multicolumn{2}{|c|}{ At the end of the research } \\
\hline & & CG & EG & CG & EG \\
\hline & & \multicolumn{2}{|l|}{$\bar{x} \pm \mathrm{m}$} & \multicolumn{2}{|l|}{$\bar{x} \pm \mathrm{m}$} \\
\hline \multirow{4}{*}{$\begin{array}{l}\text { Length of the } \\
\text { body, sm }\end{array}$} & general development & & & & \\
\hline & & $104.2 \pm 1.33$ & $104.1 \pm 1.35$ & $106.7 \pm 0.97$ & $106.9 \pm 0.83^{*}$ \\
\hline & $\begin{array}{l}\text { sanatorium and compensating } \\
\text { type*** }\end{array}$ & $109.1 \pm 0.82$ & $108.8 \pm 0.76$ & $111.3 \pm 0.78$ & $112.3 \pm 0.85^{*}$ \\
\hline & general development & & & & \\
\hline \multirow{3}{*}{$\begin{array}{l}\text { Weight of the } \\
\text { body, kg }\end{array}$} & and combined type & $16.6 \pm 0.44$ & $16.3 \pm 0.89$ & $18.3 \pm 0.35$ & $18.2 \pm 0.39 *$ \\
\hline & $\begin{array}{l}\text { sanatorium and compensating } \\
\text { type }\end{array}$ & $17.4 \pm 0.49$ & $17.1 \pm 0.56$ & $18.7 \pm 0.22$ & $18.9 \pm 0.47^{*}$ \\
\hline & general development & & & & \\
\hline \multirow{3}{*}{$\begin{array}{l}\text { Weight-height } \\
\text { index, } r \cdot \mathrm{sm}^{-1}\end{array}$} & and combined type & $162.6 \pm 4.22$ & $161.9 \pm 4.13$ & $167.2 \pm 3.71$ & $181.7 \pm 2.15^{*}$ \\
\hline & $\begin{array}{l}\text { sanatorium and compensating } \\
\text { type }\end{array}$ & $156.4 \pm 2.26$ & $156.1 \pm 2.18$ & $164.1 \pm 4.11$ & $178.2 \pm 3.67^{*}$ \\
\hline & general development & $06+1 ?$ & $0 C_{1} 12$ & ר0 0 05 & $62 *$ \\
\hline \multirow{2}{*}{$\begin{array}{l}\text { Heart rate at } \\
\text { real rest beats } \\
\min ^{-1}\end{array}$} & and combined type & $96 \pm 1.2$ & $96 \pm 1.3$ & $95 \pm 0.91$ & $90 \pm 0.63^{\top}$ \\
\hline & $\begin{array}{l}\text { sanatorium and compensating } \\
\text { type }\end{array}$ & $101 \pm 1.11$ & $101 \pm 1.23$ & $100 \pm 0.91$ & $95 \pm 0.57^{*}$ \\
\hline \multirow{3}{*}{$\begin{array}{l}\text { Vital capacity of } \\
\text { the lungs, } \mathrm{ml}\end{array}$} & $\begin{array}{l}\text { general development } \\
\text { and combined type }\end{array}$ & $1010 \pm 19.7$ & $1010 \pm 18.8$ & $1060 \pm 11.2$ & $1280 \pm 9.67 *$ \\
\hline & $\begin{array}{l}\text { sanatorium and compensating } \\
\text { type }\end{array}$ & $900 \pm 21.3$ & $900 \pm 20.8$ & $920 \pm 12.1$ & $1230 \pm 10.7^{*}$ \\
\hline & general development & & & & \\
\hline \multirow{2}{*}{$\begin{array}{l}\text { Frequency of } \\
\text { respiratory } \\
\text { cycles, } \mathrm{min}^{-1}\end{array}$} & and combined type & $25 \pm 0.66$ & $25 \pm 0.34$ & $24 \pm 0.51$ & $20 \pm 0.41^{*}$ \\
\hline & $\begin{array}{l}\text { sanatorium and compensating } \\
\text { type }\end{array}$ & $30 \pm 0.76$ & $30 \pm 0.89$ & $30 \pm 0.51$ & $26 \pm 0.32 *$ \\
\hline \multirow{2}{*}{$\begin{array}{l}\text { Ruffier Index, } \\
\text { points }\end{array}$} & $\begin{array}{l}\text { general development } \\
\text { and combined type }\end{array}$ & $8.9 \pm 0.65$ & $8.8 \pm 0.91$ & $8.7 \pm 0.51$ & $7.0 \pm 0.49 *$ \\
\hline & $\begin{array}{l}\text { sanatorium and compensating } \\
\text { type }\end{array}$ & $11.8 \pm 1.02$ & $11.7 \pm 1.14$ & $11.6 \pm 0.63$ & $9.2 \pm 0.52 *$ \\
\hline
\end{tabular}

Notes: ${ }^{*}-p<0.05$ compared to the values recorded in the control and experimental groups at the beginning and end of the experiment; ${ }^{*}$ - number of children in the institution of general development and combined type in the control group $(n=12)$, in the experimental group $(n=14) ; * *$ - number of children in the sanatorium and compensatory type institution in the control group $(n=11)$, in the experimental group $(n=12)$; EG - experimental group; KG control group.

The matic plan of the scientific research work of the Pridneprovsk State Academy of Physical Culture and Sports for 2016-2020years. "Scientific and theoretical principles of improving the process of physical education of different population groups" (number of state registration $0116 \mathrm{U} 003010$ ).

\section{Conflict of interests}

The authors state that there is no conflict of interest.

\section{References}

1. Vil'chkovs'kij ES, Denisenko NF. The organization of the motor mode of children in pre-school educational institutions. Ternopil: Traveler; 2008. (in Ukrainian)

2. Moskalenko NV. Physical education of younger students. Dnipropetrovsk: Innovation; 2014. (in Ukrainian)

3. Harrington DM, Murphy M, Carlin A, Coppinger T, Donnelly
A, Dowd KP, et al. Results From Ireland North and South's 2016 Report Card on Physical Activity for Children and Youth. Journal of Physical Activity and Health, 2016;13:S183-8. https://doi.org/10.1123/jpah.2016-0334

4. Marouli A, Papavasileiou G-E, Dania A, Venetsanou F. Effect of a psychomotor program on the motor proficiency and self-perceptions of preschool children. Journal of 
Physical Education and Sport, 2018:16(4):34-40.

5. Savich $\mathrm{E}$. The organization of motor activity in the regime of the day in the conditions of the implementation of fgos MBDOU №27 "Fairy Tale". [Internet]. 2019. [updated 2019 Jul 27; cited 2019 Nov 6]; Available from: https:// moscowyumilashes.ru/en/rody/organizaciya-dvigatelnoiaktivnosti-v-rezhime-dnya-v-usloviyah-realizacii.html

6. Moskalenko NV, Polyakova AV, Reshetilova VM. Modeling of rational motor mode of children 3-4 years in different kindergartens. Sportivnij visnik Pridniprov'ia, 2016; 3:151157. (in Ukrainian)

7. Suporosova IN. Organization of the regime of the day in a preschool educational institution for children with visual impairment in accordance with FGT. Theory and Practice of Education in the Modern World. St. Petersburg, May 2013. St. Petersburg: Renome; 2013. (in Russian)

8. Panhelova NE. Theoretical and methodological principles of formation of a harmoniously developed personality of a preschool child in the process of physical education. [Ph.D Thesis]. Kiev; 2014. (in Ukrainian)

9. Honchar LV, Borysova YuYu.Analysis of indicators of physical development of older preschool children. Slobozhanskyi herald of science and sport, 2019; 2: 50-54. (in Ukrainian) https://doi.org/10.15391/snsv.2019-2.008

10.Stork S, Sanders W. Physical Education in Early Childhood. The Elementary School Journal, 2008;108(3): 197-206. https://doi.org/10.1086/529102

11.Panhelova N, Tsapuk D. Oriental health systems in physical education of older preschool children. Sportivnij visnik Pridniprov'ia. 2018; 1: 222-225. (in Ukrainian)

12.Panhelova N, Tsapuk D. Application of elements of oriental wellness systems in physical education of older preschool children: a theoretical and methodological aspect. Sportivnij visnik Pridniprov'ia, 2018; 2: 107-111. (in Ukrainian)

13.Lakhno $\mathrm{OH}$. Innovative technologies of development of psychomotor abilities in physical education of children of 2 - 5 years of life. [Ph.D Thesis]. Kiev; 2013. (in Ukrainian)

14.Bondar EM. Correction of functional disorders of the musculoskeletal system of children 5-6 years, taking into account the spatial organization of their body. [Ph.D Thesis]. Kiev; 2009. (in Russian)

15.Yousefipoor F, Nafisi V. A Novel Method for Pulsometry Based on Traditional Iranian Medicine. J Med Signals Sens. 2015; 5(4): 230- 7. https://doi.org/10.4103/2228-7477.168650

16.Spirometry [Internet]. 2019. [updated 2019 Jul 27; cited 2019 Nov 6]; Available from: https://www.physio-pedia.com/ Spirometry

17. What is the Ruffier test and what does it need the [Internet]. 2013. [updated 2019 Jul 27; cited 2019 Nov 6]; Available from: http://doshkolenok.kiev.ua/zdorovje-doshkolni $\mathrm{ka} / 949-2013-08-14-05-27-17 . h t m l$ (in Russian)

18.Saikyna EH. Fitness in the modernization of physical education of children and adolescents in modern sociocultural conditions. St. Petersburg: Education; 2008. (in Russian)

19.Polyakova AV. Organizational and methodological foundations of motor mode of children 3-4 years in preschool institutions of various types. [Ph.D Thesis]. Dnipropetrovsk; 2015. (in Ukrainian)

20.Holubeva HN. Formation of the motor mode of the child (up to 6 years). Moscow: The theory and practice of physical culture and sport; 2009. (in Russian)

\section{Information about the authors:}

Moskalenko N.V.; http://orcid.org/0000-0001-9162-5206; admin_infiz@ukr.net; Dnieper State Academy of Physical Culture and Sports; Naberezhna Pobedy str., 10, Dnieper, 49094, Ukraine.

Savchenko V.G.; http://orcid.org/0000-0002-3839-6595; admin_infiz@ukr.net; Dnieper State Academy of Physical Culture and Sports; Naberezhna Pobedy str., 10, Dnieper, 49094, Ukraine.

Polyakova A.V.; http://orcid.org/0000-0002-4328-6083; admin_infiz@ukr.net; Dnieper State Academy of Physical Culture and Sports; Naberezhna Pobedy str., 10, Dnieper, 49094, Ukraine.

Mikitchik O.S.; (Corresponding author); http://orcid.org/0000-0002-0047-4359; molga.0604@gmail.com; Dnieper State Academy of Physical Culture and Sports; Naberezhna Pobedy str., 10, Dnieper, 49094, Ukraine.

Mitova E.A.; https://orcid.org/0000-0002-4309-9261; elenamitova@ukr.net; Dnieper State Academy of Physical Culture and Sports; Naberezhna Pobedy str., 10, Dnieper, 49094, Ukraine.

Griukova V.V.; https://orcid.org/0000-0002-8947-0521; admin_infiz@ukr.net; Dnieper State Academy of Physical Culture and Sports; Naberezhna Pobedy str., 10, Dnieper, 49094, Ukraine.

Mytsak A.V.; http://orcid.org/0000-0003-0879-3618; admin_infiz@ukr.net; Dnieper State Academy of Physical Culture and Sports; Naberezhna Pobedy str., 10, Dnieper, 49094, Ukraine.

Cite this article as:

Moskalenko NV, Savchenko VG, Polyakova AV, Mikitchik OS, Mitova OO, Griukova VV, Mytsak AV. Physical condition of pupils of pre-school educational establishments of different types. Pedagogy of physical culture and sports, 2020;24(2):77-84. https://doi.org/10.15561/26649837.2020.0205

This is an Open Access article distributed under the terms of the Creative Commons Attribution License, which permits unrestricted use, distribution, and reproduction in any medium, provided the original work is properly cited (http://creativecommons.org/licenses/by/4.0/deed.en). 